\title{
Populismo e historiografia na atualidade: lutas operárias, cidadania e nostalgia do varguismo
}

Felipe Demier ${ }^{*}$

\begin{abstract}
Resumo: O presente artigo tem por objetivo levar a cabo uma discussão acerca do movimento de revisão historiográfica do populismo. Bastante em voga nas décadas de 1960, 1970 e 1980, as interpretações historiográficas sobre o período 1930-1964 baseadas na noção de "populismo" passaram a ser criticadas de modo mais enfático nas últimas duas décadas. Nas páginas deste artigo, abordaremos, de forma crítica, duas das principais correntes que conduziram (conduzem) esse movimento de revisão historiográfica do populismo, o qual parece ganhar cada vez mais adeptos nos espaços acadêmicos e midiáticos.
\end{abstract}

Palavras-chave: Populismo; Revisionismo; Trabalhismo.

Abstract: This paper aims to carry out a discussion on the movement of historiographical revision of populism. Quite in vogue in the 1960's, 1970's and 80's, historiographical interpretations over the period 1930-1964 based on the notion of "populism" began to be criticized most emphatically in the last two decades. In the pages of this article, we will discuss, critically, the two main currents that led (lead) the movement of historiographical revision of populism, which seems to gain more and more followers in the media and academic spaces.

Keywords: Populism; Revisionism; Labor Movement.

Nos últimos anos, os vocábulos "populismo" e "populistas", em suas acepções mais liberais e vulgares, voltaram a ser utilizados em larga escala nos mass media brasileiros. Um tanto quanto indiscriminadamente, costumam ser empregados para se referir pejorativamente a quaisquer governos e governantes que, mais em termos retóricos do que práticos, procuram se distanciar do dogma neoliberal e ousam questionar a infalibilidade papal de Washington. Assim, Hugo Chávez, Evo Morales, Rafael Corrêa, Daniel Ortega, e até mesmo o ex-presidente Luís Inácio Lula da Silva, são tachados sumariamente de "populistas". De uma verborragia anti-imperialista a um simples aumento do salário mínimo, passando pela ampliação de programas assistencialistas focalizados, tudo é visto como "populismo" pelos editores da grande imprensa. Com suas irascíveis críticas às lideranças "demagógicas" que buscam sustentação político-social nas sempre "perigosas" massas populares, o vil jornalismo político da atualidade parece fantasticamente nos conduzir de volta às décadas de 1950 e 1960. Também pela historiografia brasileira atual, a polarização daquelas agitadas décadas foi trazida à tona novamente, como objeto de estudo. No polo oposto dos escribas midiáticos de ontem e de hoje (embora dispondo de um significativo espaço nos jornais e programas televisivos), alguns conhecidos historiadores levaram a cabo nas últimas décadas - e o continuam fazendo - um movimento de reabilitação historiográfica do populismo

\footnotetext{
${ }^{*}$ Doutor em História pela Universidade Federal Fluminense - felipedemier@yahoo.com.br
} 
brasileiro e de suas lideranças políticas. Esses pesquisadores opuseram-se, desse modo, tanto às concepções teóricas formalistas e abertamente antipopulares, que condenaram o populismo por seu distanciamento da democracia liberal institucionalizada quanto, principalmente, a uma historiografia marxista que vira naquele uma forma específica de dominação política de classe num período de acelerada urbanização e industrialização do país.

Buscando se diferenciar desses dois extremos interpretativos, os historiadores revisionistas ${ }^{1}$ rejeitaram a própria ideia de populismo: se, antes - disseram eles -, o termo teria servido de acusação a Vargas e outras lideranças políticas "populares" por parte das "elites" adeptas da exclusão política das massas, depois, tal conceito teria ganhado um estatuto conceitual por meio das linhas de intelectuais marxistas que, desejosos de uma revolução socialista nos moldes leninistas, voltaram suas baterias contra o varguismo (numa espécie de "aliança tácita", em termos de teoria, com aquelas "elites"). Assim, no lugar do populismo, os revisionistas propuseram, já há algum tempo, o conceito de "trabalhismo", o qual vem paulatinamente ganhando mais espaço nas novas pesquisas históricas sobre o Brasil contemporâneo. Tendo o conflito político do período populista reduzido a uma simples disputa entre "trabalhistas" e "elites antipopulares", os historiadores revisionistas colocaram-se claramente ao lado dos primeiros. Prioritariamente, dirigiram suas críticas aos cientistas sociais marxistas que, nos anos 60 e 70 do século passado, teriam menosprezado as diferenças entre ambas, construído uma visão negativa do "trabalhismo" (batizando-o de populismo).

O movimento de revisão historiográfica do populismo, entretanto, é mais amplo e sofisticado do que sua corrente revisionista, congregando também, por exemplo, autores que, mais à esquerda no plano teórico-político, expuseram a existência de inúmeras e combativas lutas operárias entre 1930 e 1964, questionando, desse modo, a tese de um "sindicalismo populista" tal como fora proposta pelos formuladores marxistas do populismo, isto é, a de um movimento sindical integralmente subsumido à lógica estatal-populista. Embora significativamente distintos dos revisionistas, também esses historiadores, a nosso ver, deixaram se levar, de certa forma, pelo discurso dos atores políticos da época; agora não mais pelo dos chefes de estado e lideranças políticas "populistas"/"trabalhistas", mas sim pelo dos dirigentes sindicais reformistas, ligados, em grande parte, ao Partido Comunista Brasileiro (PCB). Ao mesmo tempo em que iluminaram as antes obscurecidas mobilizações operárias ocorridas no período 1930-1964, esses revisores do populismo - mas não revisionistas! - procuraram reabilitar também muitos daqueles que as dirigiram, e que o fizeram, em última análise (e, às vezes, em primeira) por um viés de "colaboração de classe",

\footnotetext{
${ }^{1}$ A alcunha de "revisionistas" (de longa tradição nos debates marxistas) foi empregada pelo filósofo marxista Caio Navarro de Toledo para se referir aos historiadores que, a partir de 2004, começaram a defender mais abertamente uma revisão conservadora das interpretações sobre o Golpe de 1964 (TOLEDO, Caio Navarro de. "As falácias do revisionismo". In: Crítica Marxista, n.o 19. Campinas, 2004, p. 27-48). Tomamos aqui o termo emprestado de Toledo, até porque, para além do caráter do debate que aqui propomos (de perspectiva similar ao realizado pelo filósofo marxista), muitos dos historiadores revisionistas do populismo por nós abordados são justamente os mesmos responsáveis pela tal revisão conservadora do Golpe de1964.
} 
pautado pela lógica da "cidadania". De certo modo, pode-se dizer que esses historiadores acabaram por reificar algumas formas rebaixadas de subjetividade apresentadas pelo proletariado brasileiro de então. Terminologicamente - vale antecipar -, não chegaram a recusar o uso do conceito de populismo.

Este artigo tem por finalidade abordar criticamente esse heterogêneo movimento de revisão historiográfica sobre o populismo brasileiro. Primeiramente, faremos um debate científico e fraternal com um dos campos desse movimento, mais especificamente, com uma das correntes que o constituem, composta pelos historiadores aos quais nos referimos (ainda que sem nomeá-los) no parágrafo acima. Depois, finalmente, chegaremos ao debate, duro porquanto politicamente mais necessário que o anterior, com a corrente revisionista.

\section{A TEORIA DO POPULISMO EM XEQUE: OS DOIS CAMPOS DA REVISÃO HISTORIOGRÁFICA EM CURSO}

Desde meados da década de 1960, particularmente após o Golpe de Estado de 1964, parcela expressiva de pesquisadores das áreas de sociologia e ciência política dedicou-se à compreensão do papel desempenhado pela classe trabalhadora em diversos âmbitos da vida nacional, com destaque para as conexões existentes entre o desenvolvimento urbanoindustrial do país e as estruturas político-representativas dos trabalhadores a partir de 1930. Destarte, tiveram lugar seminal trabalhos sobre o que hoje se costuma denominar "mundo do trabalho". Ligados à Universidade de São Paulo (USP) e herdeiros do antigo Centro de Sociologia da Indústria e do Trabalho (CESIT), intelectuais como Fernando Henrique Cardoso, Octavio lanni, José Albertino Rodrigues, Maria Sylvia de Carvalho Franco, Luiz Pereira, Paul Singer, Juarez Brandão Lopes, Leôncio Martins Rodrigues, Boris Fausto, José de Souza Martins, Gabriel Cohen e Francisco Weffort, muitos deles orientados (formal ou informalmente) por Florestan Fernandes, realizaram consagrados trabalhos acerca de temáticas como industrialização, urbanização, empresariado, movimento operário, sindicalismo, conflito social, estado e desenvolvimento econômico. ${ }^{2}$

Muitos dos cientistas sociais dessa geração, com destaque para o cientista político Francisco Weffort e o sociólogo Octavio lanni, se puseram a interpretar o processo de incorporação das massas populares ao processo político brasileiro no pós-1930, tomando por centro as políticas estatais de cunho social e, em especial, a formatação da estrutura sindical brasileira de matriz corporativista. "Manobrados" por intermédio das primeiras e controlados severamente pela segunda, os trabalhadores brasileiros foram vistos como um dos fundamentais elementos constitutivos de um período histórico (1930-1964) qualificado de "populista". Nessa linha interpretativa, o movimento operário, privado de autonomia sindical e politicamente "desviado" por suas direções, teria se tornado, desde a ascensão de Getúlio Vargas ao poder, um importante apoio social para um estado que buscava acomodar

\footnotetext{
2 Um bom e sintético trabalho acerca dessa "corrente" intelectual é SILVA, Luiz Fernando da. Pensamento social brasileiro. Marxismo acadêmico entre 1960 e 1980. São Paulo: Corações \& Mentes, 2003.
} 
os interesses das frações da classe dominante em um momento de "crise de hegemonia" aberto com a crise do sistema oligárquico agroexportador. ${ }^{3}$

Ao longo das décadas de 1970 e 1980, o viés analítico descrito acima acabaria por orientar inúmeros trabalhos acadêmicos sobre a classe trabalhadora brasileira e suas organizações sindicais e políticas do período 1930-1964. ${ }^{4}$ Iniciada em fins dos anos 70, a ascensão sindical e política da classe trabalhadora brasileira contribuiria para reforçar a "teoria do populismo" ${ }^{5}$ nos ambientes de pesquisa social. Objeto de estudo de diversos cientistas sociais, o chamado "novo sindicalismo", pelas próprias questões práticas que colocava (luta contra a legislação sindical corporativista, defesa da organização sindical pela base etc.) funcionou como uma espécie de acicate para estudos historiográficos sobre a classe trabalhadora no período pré-1930, visto como um momento no qual os trabalhadores ainda gozariam de uma autonomia organizativa, em contraste com a posterior tutela estatal sobre o movimento sindical (elemento central nas elaborações sobre o populismo). ${ }^{6}$

\footnotetext{
${ }^{3}$ Entre várias outras obras de lanni e Weffort, ver especialmente a coletânea WEFFORT, Francisco. O populismo na política brasileira. Rio de Janeiro: Paz e Terra, 1978 e IANNI, Octavio. O colapso do populismo no Brasil. Rio de Janeiro: Civilização Brasileira, 1968.

${ }^{4}$ A historiadora Virgínia Fontes afirma que a matriz explicativa oferecida por Weffort para a "Revolução de 1930" - marco inicial do "populismo" -, calcada na ideia de "crise de hegemonia", tornou-se preponderante nas ciências sociais do país, "figurando inclusive em livros didáticos". FONTES, Virgínia. "Que hegemonia? Peripécias de um conceito no Brasil". In:__. Reflexões im-pertinentes. História e capitalismo contemporâneo. Rio de Janeiro: Bom Texto, 2005, p. 202. Vale ressalvar, contudo, que, nesse mesmo período (décadas de 1970 e 1980), as temáticas vinculadas ao movimento operário da etapa 1930-1964 receberam também abordagens distintas das referendadas no conceito de "populismo"; possivelmente o caso mais exemplar seja o clássico trabalho do cientista político Luiz Werneck Vianna sobre a estrutura sindical brasileira (VIANNA, Luiz Werneck. Liberalismo e sindicato no Brasil. Rio de Janeiro: Paz e terra, 1976).

${ }^{5}$ Esclarecemos que aqui designamos de "teoria do populismo" (ou "teoria populista") o conjunto das elaborações marxistas que propuseram a categoria de populismo como chave interpretativa da natureza de certos sistemas políticos latino-americanos surgidos no pós-crise de 1929 e extintos pela sequência de golpes civil-militares perpetrados nas décadas de 1960 e 1970. Particularmente no que diz respeito ao Brasil, a "teoria do populismo (brasileiro)" se constitui em um modelo explicativo, elaborado principalmente por Francisco Weffort e Octavio lanni, das relações políticas existentes entre classes sociais e estado durante o período 19301964. Nesse sentido, não estamos tratando de uma teoria propriamente dita (como uma teoria do estado ou uma teoria das classes sociais, por exemplo), mas de um conjunto analítico dotado de um forte teor teórico, como veremos. Por fim, ao falarmos de "teóricos do populismo", nos referimos, evidentemente, aos autores responsáveis pelas elaborações sobre o populismo, principalmente (mais uma vez) os próprios Weffort e lanni. Dito isso, não utilizaremos mais aspas ao nos referirmos tanto à "teoria do populismo" ("teoria populista"), quanto aos seus criadores ("teóricos do populismo"). Alertamos ainda que ao falar de uma teoria do populismo e de seus autores (teóricos do populismo) não nos referimos a uma teoria produzida pelo regime populista e aos seus criadores, preferindo usar, nesses casos, respectivamente, as denominações de ideologia do populismo (ou ideologia populista) e ideólogos do populismo (ou ideólogos populistas).

"Um dos primeiros trabalhos produzidos sob a "inspiração" do "novo sindicalismo" acerca dos primeiros passos da classe trabalhadora foi HARDMAN, Foot; LEONARDI, Victor. História da indústria e do Trabalho no Brasil. Das origens aos anos vinte. São Paulo: Global, 1982. Contudo, ainda nos anos de 1970, havia sido publicado, dentre outros poucos títulos relacionados ao tema dos trabalhadores na Primeira República, o conhecido trabalho historiográfico de Boris Fausto, intitulado Trabalho urbano e conflito social (1890-1920). (São Paulo: Difel, 1976). Nos anos de 1980 e 90, muitos autores (adeptos ou não das teses weffortianas sobre o "sindicalismo populista") se dedicaram à investigação do "novo sindicalismo". Entre outros trabalhos sobre o tema, citamos: MOISÉS, José Álvaro. "As estratégias do novo sindicalismo". In: Revista de cultura política, n.o 5 e 6. Rio de Janeiro: Paz e Terra, 1981; ALMEIDA, Maria Hermínia Tavares de. "O sindicalismo brasileiro entre a conservação e a mudança”. In: Sociedade e política no Brasil pós-1964. 2.a edição. São Paulo: Brasiliense, 1984;
} 
Se a precedência dos estudos sobre o "mundo do trabalho" coube, em grande parte, aos sociólogos e cientistas políticos, a partir da década de 1980, muitos historiadores finalmente lançaram-se nas investigações sobre a história da classe trabalhadora brasileira e suas lutas sindicais e políticas. Em um primeiro momento, as pesquisas concentraram-se temporalmente nos anos da Primeira República, tomados, conforme dito no parágrafo anterior, como uma fase "autônoma" do movimento operário. Com o avançar da década, o período republicano pós-1930, com destaque para o balizamento 1945-1964, passou a receber também atenção especial dos estudiosos. Iniciava-se, assim, aquilo que denominamos como um movimento de revisão historiográfica do período populista da história republicana brasileira. Tal movimento, como já antecipamos, não é dotado de homogeneidade analítica, teórica e política, e nele podem ser entrevistos pelo menos dois grandes campos, dois diferentes caminhos interpretativos - que por vezes se cruzam, é verdade - acerca das relações entre estado e classe trabalhadora durante o travejamento temporal 1930-1964.

A trajetória de um desses campos remonta a 1988, quando a historiadora Angela de Castro Gomes publicou sua tese de doutoramento sob o título de $A$ invenção do trabalhismo, ${ }^{7}$ provocando substantivas alterações no curso dos debates referentes ao período em questão. Teve lugar, então, uma sequência, ainda em andamento, de críticas à forma como a relação entre poder estatal e trabalhadores no pós-1930 vinha sendo compreendida nos meios acadêmicos dedicados ao tema, ainda fortemente influenciados pelas abordagens de Weffort e lanni. Criticando o papel "passivo", de "objeto", supostamente conferido aos trabalhadores do período 1930-1964 pelas análises então vigentes, Gomes propôs a categoria de "trabalhismo", inicialmente como uma rejeição implícita ao conceito de populismo. Segundo a autora, o termo "populismo" seria dotado de tom pejorativo e associado a uma relação de manipulação entre um estado/sujeito e trabalhadores/objetos. Buscava-se, como a própria autora depois salientaria, entender os mecanismos de interlocução entre estado e trabalhadores, procurando atribuir a estes últimos "um papel de sujeito que realiza escolhas segundo o horizonte de um campo de possibilidades". 8

SADER, Eder. Quando novos personagens entram em cena. Experiências e lutas dos trabalhadores da grande São Paulo 1970-1980. Rio de Janeiro: Paz e Terra, 1988; RODRIGUES, Leôncio Martins. "As tendências políticas na formação das centrais sindicais". In: BOITO Jr., Armando (org.) O sindicalismo brasileiro nos anos 80 . Rio de Janeiro: Paz e Terra, 1990 e CUT: os militantes e a ideologia. Rio de Janeiro: Paz e Terra, 1990; BOITO Jr., Armando. "Reforma e persistência na estrutura sindical brasileira". In: O sindicalismo brasileiro nos anos 80. Op. cit.; ANTUNES, Ricardo. A rebeldia do Trabalho. O confronto operário no ABC Paulista: as greves de 1978-1980. 2.a edição. Campinas; EdUNICAMP, 1992, e O novo sindicalismo no Brasil. 2a edição. Campinas: Pontes, 1995; MATTOS, Marcelo Badaró. Novos e velhos sindicalismos no Rio de Janeiro (1955-1988). Niterói: Vício de Leitura, 1998.

${ }^{7}$ GOMES, Angela de Castro. A invenção do trabalhismo. São Paulo: Vértice, 1988.

${ }^{8}$ GOMES, Angela de Castro. "O populismo e as ciências sociais no Brasil: notas sobre a trajetória de um conceito". In: FERREIRA, Jorge (org.). O populismo e sua história. Debate e crítica. Rio de Janeiro: Civilização Brasileira, 2001, p. 46. 
De certa forma, Angela Gomes fez escola, e seguiram-se várias pesquisas imbuídas da missão de propor explicitamente uma substituição direta do conceito de populismo pelo de "trabalhismo". Formava-se, assim, um dos campos - e talvez o mais cool entre as novas gerações de historiadores e jornalistas políticos - do referido movimento de revisão historiográfica, campo esse que aqui denominamos de revisionista (conforme anunciamos na introdução). Em trabalhos polêmicos datados de 2001, os historiadores Jorge Ferreira ${ }^{9}$ e Daniel Aarão Reis Filho ${ }^{10}$ realizaram análises críticas concernentes à categoria de populismo, colimando demonstrar sua total ineficácia como instrumental explicativo das relações entre estado e trabalhadores no período situado entre as ditaduras do Estado Novo e militar.

O outro campo da revisão historiográfica do populismo (também já mencionado em nossas páginas introdutórias) foi constituído por sugestivas pesquisas produzidas na década de 1990 voltadas para o estudo das lutas operárias no pós-1930, em especial no pós-1945. Construídas a partir de sólida análise de fontes primárias pouco exploradas e conferindo um novo valor a entrevistas com militantes sindicais da época, tais pesquisas lançaram luz sobre diversas experiências concretas dos trabalhadores no período, expondo sua capacidade mobilizatória e organizativa, assim como sua utilização própria da legislação trabalhista nos embates com o capital. Questionando historiograficamente a ideia de uma adscrição total dos setores explorados ao estado e aos políticos "demagógicos", esses estudos opuseram-se às teses de Weffort e lanni acerca de uma classe trabalhadora que, adormentada pela "política de massas" e repressão estatais, teria, ao longo do populismo, se portado ideologicamente como "massa", e não como "classe". ${ }^{11}$

\footnotetext{
${ }^{9}$ FERREIRA, Jorge. "O nome e a coisa: o populismo na política brasileira". In: história. Debate e crítica. Op. cit., p. 59-124.

${ }^{10}$ REIS FILHO, Daniel Aarão. "O colapso do colapso do populismo ou a propósito de uma herança maldita". In: FERREIRA, Jorge (org.). O populismo e sua história. Op. cit., p. 319-377.

${ }^{11}$ À guisa de exemplo, citamos alguns trabalhos imbuídos, em maior ou menor grau, dessa perspectiva: COSTA, Hélio da. Em busca da memória: comissão de fábrica, partido e sindicato no pós-guerra. São Paulo: Scritta, 1995; SILVA, Fernando Teixeira da. A carga e a culpa. Operários das docas de Santos: direitos e cultura de solidariedade. 1937-1968. São Paulo: Hucitec/Pref. Municipal de Santos, 1995; FORTES, Alexandre (e outros) Na luta por direitos. Campinas: EdUnicamp, 1999; __. Nós do Quarto Distrito: a classe trabalhadora portoalegrense e a era Vargas. Caxias do Sul: Edusc/Rio de Janeiro: Garamond, 2004; NEGRO, Antonio Luigi. Linhas de montagem. $O$ industrialismo nacional-desenvolvimentista e a sindicalização dos trabalhadores. São Paulo: Boitempo, 2004; FONTES, Paulo. Um Nordeste em São Paulo: trabalhadores migrantes em São Miguel Paulista (1945-1966). Rio de Janeiro: FGV, 2008; SILVA, Maria Carolina G. A greve dos tecelões cariocas: partidos e sindicatos no Segundo Governo Vargas. Niterói, UFF, 1995. Dissertação (Mestrado em História); OLIVEIRA, Ana Lúcia V. de Santa Cruz. Sindicato e sindicalismo bancário. Rio de Janeiro: EDUR/SEEB-RJ, 1998; MATTOS, Marcelo Badaró. Novos e velhos sindicalismos no Rio de Janeiro. Op. cit.; ABREU, Paulo Tenório de. As greves no Rio de Janeiro (1955-1964). Niterói: UFF, 2001. Dissertação (Mestrado em História Social); ALMEIDA, Antonio de. Lutas, organização coletiva e cotidiano. Cultura e política no ABC paulista. 1930-1980. São Paulo: USP, 1996. Tese (Doutorado em História Social); VARUSSA, Rinaldo José. Trabalho e legislação: experiências de trabalhadores na Justiça do Trabalho. São Paulo: PUC-SP, 2002; FRENCH, John D. O ABC dos operários. Conflitos e alianças de classe em São Paulo, 1900-1950. São Paulo: Hucitec/Pref. Mun. de São Caetano do Sul, 1995 e Afogados em leis. A CLT e a cultura política dos trabalhadores brasileiros. São Paulo: Perseu Abramo, 2001. Vale destacar que parte significativa dessa leva de trabalhos é caracterizada também pelo recurso à interdisciplinaridade - elemento, aliás, marcante dos estudos sobre o "mundo do trabalho" no Brasil desde seus primórdios - e o olhar enfático sobre várias dimensões da vida social da classe trabalhadora, tais como cultura, moradia, cotidiano etc., até então relegadas a segundo plano pela prática historiográfica.
} 
Como parte integrante e expressiva deste campo, localizamos a existência de uma importante corrente constituída por destacados intelectuais que, individual e coletivamente, realizaram pesquisas acadêmicas vinculadas a determinados programas de pós-graduação da Universidade de Campinas (Unicamp - SP).

No breve exercício de debate historiográfico que aqui propomos, nos deteremos primeiramente sobre essa corrente campineira.

\section{POPULISMO E “LUTA POR DIREITOS”: A CORRENTE HISTORIOGRÁFICA DA UNICAMP}

Composta em grande parte por historiadores afeitos às contribuições da chamada história social inglesa e ligados ao Partido dos Trabalhadores (PT), tal corrente rejeitou a afirmação da existência de uma "heteronomia" da classe trabalhadora durante os anos de 1930-1964 e, adotando uma concepção mais elástica do conceito de "consciência de classe", de inspiração thompsoniana, tomou muitas das atitudes dos trabalhadores ocorridas nesse período como legítimas atitudes classistas. ${ }^{12}$

Debruçando-se sobre vasta documentação escrita e oral concernente à vida sindical de diversas categorias de profissionais a partir da década de 1930, esses pesquisadores se depararam com uma série de manifestações dos trabalhadores que extrapolou os limites impostos às atividades da classe pela legislação corporativista que regia o funcionamento dos sindicatos. O cuidadoso trabalho feito com publicações operárias, atas sindicais e depoimentos orais de ex-ativistas, entre outras fontes, acabou por dar luz à presença, sob a vigência do populismo, de atuantes "comissões de fábricas" e outras formas organizativas por local de trabalho, assim como a vários movimentos paredistas que utilizaram, a seu modo e dentro das possibilidades reais, as controladas entidades sindicais. Graças a tais pesquisas, tomou-se conhecimento das astuciosas formas inventadas pelas bases sindicais para "driblar" os interventores estatais, como também dos muitos casos em que estas foram, na prática, além das intenções dos seus dirigentes e líderes de perfil "colaboracionista". A coerente conclusão de tal corrente historiográfica é a de que, se por um lado é verdade que a tutela do estado populista sobre as organizações associativas de classe impôs significativos limites às mobilizações autônomas dos trabalhadores, por outro, pode-se assegurar que aquela não se erigiu em um insuperável óbice para estas.

Uma síntese dessa leitura alternativa sobre o papel desempenhado pela classe trabalhadora sob o populismo encontra-se exposta, ente outros lugares, na conclusão de uma das interessantes pesquisas de Hélio da Costa, expoente da corrente em questão:

\footnotetext{
${ }^{12}$ Como componentes dessa corrente, destacamos os jovens historiadores Alexandre Fortes, Antonio Luigi Negro, Fernando Teixeira da Silva, Hélio da Costa e Paulo Fontes, todos eles orientados em seus doutorados realizados na Unicamp, formal ou informalmente, pelos historiadores Marco Aurélio Garcia e Michael Hall. Duas outras importantes influências para o jovem grupo de historiadores campineiros são a socióloga Maria Célia Paoli (USP) e o historiador, também brasilianista norte-americano, John French (Duke University).
} 
Tivemos acesso a várias fábricas e oficinas, onde eles [os trabalhadores] faziam circular abaixo-assinados, elegiam comissões de representantes, organizavam greves, enfrentavam a repressão.

Entramos no recinto dos sindicatos e nos deparamos com suas dependências lotadas em concorridas assembleias às vésperas de muitas greves. Em outros momentos fomos tomados por um clima tenso nos sindicatos, marcado pela repressão, com interventores e policiais voltando à cena. Os frequentes conflitos entre comunistas e ministerialistas pelas direções dos sindicatos também fizeram parte do seu cotidiano nessa década [1943-1953] [...].

Ao se apoderarem dos sindicatos, os ativistas utilizavam suas brechas legais contra as arbitrariedades patronais [...]. Mesmo nos momentos mais difíceis enfrentados pelo movimento sindical, como foi o caso do período 1947/1950, os seus ativistas conseguiram, mesmo sendo vitimados pela repressão, encontrar subterfúgios para manterem sua militância [...].

Em suma, mesmo nos piores momentos, os trabalhadores tinham noção das regras do jogo e buscavam alterá-las, embora conhecendo seus limites. É importante atentarmos para este aspecto para entendermos a rejeição de boa parte dos ativistas sindicais a abandonarem os sindicatos oficiais como espaço de militância $[\ldots]$.

As lutas travadas nesse período foram lutas profundamente enraizadas nos locais de trabalho e adquiriram, sempre que a conjuntura política permitiu, um caráter de massa expressivo. Nesse sentido, a fábrica, as ruas e os sindicatos não foram espaços excludentes da luta operária. ${ }^{13}$

Como se pode notar, tal perspectiva interpretativa sobre a dinâmica sindical do período vai de encontro ao modelo de "sindicalismo populista", no qual o movimento sindical aparece, como vimos, dotado de uma natureza eminentemente "burocrática", "cupulista" e "colaboracionista", pois distante das demandas econômicas de suas bases, composto por estruturas verticalizadas (como as chamadas "organizações paralelas") e adepto de seu próprio atrelamento ao estado.

No mesmo exercício crítico de verificação histórica, outro elemento constitutivo da teoria "populista" relativizado por autores como Hélio da Costa é a assertiva de que a bemsucedida "manobra" das massas populares pelo estado - isto é, o "desvio" daquelas de seus reais interesses por parte deste - teve no papel desempenhado pelas direções políticas da classe operária, com destaque para o PCB, um de seus principais pontos de apoio. Como foi visto, na ótica de autores como lanni e Weffort, a política comunista, pouco crítica à estrutura sindical corporativista, enredada no projeto "nacionalista" de aliança de classes e marcada por práticas burocráticas, teria funcionado como uma importante engrenagem na prestidigitadora máquina populista. Por outro ângulo analítico, a historiografia operária da Unicamp buscou ressaltar a forte penetração do PCB entre as mais diversas categorias de trabalhadores e valorizar o papel exercido por sua militância no período 1930-1964. Em investigações empíricas, foram visualizados não desprezíveis desencontros entre as deliberações políticas oficiais da direção do PCB, mais moderadas, e a atuação concreta, por vezes mais combativa e radicalizada, dos comunistas junto ao cotidiano da classe trabalhadora.

${ }^{13}$ COSTA, Hélio da. Em busca da memória: comissão de fábrica, partido e sindicato no pós-guerra. São Paulo: Scritta, 1995, p. 199-203. 
No encontro com os trabalhadores nos seus locais de trabalho deparamo-nos com a presença marcante do Partido Comunista Brasileiro no cotidiano fabril e nas mobilizações de massa desse período. O PCB era a grande novidade política. Era o partido da "ordem e tranquilidade", da "Constituinte com Getúlio", mas era simultaneamente o partido das ruas, das praças, das festas populares, dos bairros operários, das fábricas e, enquanto organização partidária, foi praticamente o único a exercer forte sedução sobre a classe trabalhadora e a juventude. ${ }^{14}$

Seguidas vezes encontramo-nos com o Partido Comunista Brasileiro nas nossas andanças pelas décadas de 1940 e 1950, marcando sua presença nos locais de trabalho, nos sindicatos e nas ruas. O PCB foi, sem sombra de dúvida, a corrente política de maior influência no movimento operário. Sua conduta, porém, foi marcada pela ambiguidade. Tentou sem sucesso ser o partido da ordem e, ao mesmo tempo, como partido que se propunha a representar os trabalhadores, não podia isolar-se das suas lutas. O resultado foi o constante desencontro entre a direção e a base do partido. ${ }^{15}$

Em função dessa "ambiguidade", Hélio da Costa chegou até mesmo a propor a existência de "dois PCs" no período em questão:

Afinal, o que foi o Partido Comunista Brasileiro nesse período? Uma confrontação da prática desse partido com o movimento operário mostrará que ele dela se separa e se funde ao mesmo tempo. Em outras palavras, o PCB não era um bloco monolítico em que sua prática e o seu discurso se articulavam de forma coerente e harmoniosa todo o tempo. Havia dois PCs na realidade. Um PC mais ligado à cúpula do discurso oficial que apelava para as massas "apertarem os cintos", buscando congelar suas demandas imediatas; e outro que convivia com um ativismo intenso nas bases do partido nos bairros, nas fábricas, colocando-se à frente de muitas dessas reivindicações consideradas temerárias pela direção do partido. ${ }^{16}$

Fernando Teixeira da Silva, outro representante da corrente historiográfica em tela, corroborando a visão acima, foi ainda mais longe em sua objeção às teses de Weffort e lanni que realçaram os equívocos cometidos pelos comunistas sob o populismo. Em um sintético artigo $^{17}$, resultante de sua pesquisa de fôlego sobre as lutas dos portuários de Santos (SP) entre $1937-1968^{18}$, Teixeira da Silva almejou reabilitar política e sindicalmente não só as lideranças comunistas da cidade, como também as petebistas (trabalhistas) - ligadas ao Partido Trabalhista Brasileiro - PTB - as quais estiveram à frente das entidades sindicais (como o Sindicato dos Operários dos Serviços Portuários de Santos - Sosps) e intersindicais (como o Fórum Sindical de Debates - FSD - e a União dos Sindicatos da Orla Marítima de

\footnotetext{
${ }^{14}$ COSTA. Hélio da. Em busca da memória... Op. cit., p. 6.

${ }^{15}$ Idem, p. 199-200.

${ }^{16}$ Idem, p. 8. A tese que propõe a existência de "dois PCs" durante certos momentos do período populista encontra-se também, com suas devidas particularidades, em trabalhos como MATTOS, M. Badaró. Novos e velhos sindicalismos no Rio de Janeiro. Op. cit. e SANTANA, Marco Aurélio. Homens partidos. Comunistas e sindicatos no Brasil. São Paulo: Boitempo, 2001.

${ }^{17}$ SILVA, Fernando Teixeira da. "Direitos, política e trabalho no Porto de Santos". In: FORTES, Alexandre, et. al. Na luta por direitos. Campinas: EdUnicamp, 1999, p. 51-86.

${ }^{18}$ SILVA, Fernando Teixeira da. A carga e a culpa. Operários das docas de Santos: direitos e cultura de solidariedade. 1937-1968. São Paulo: Hucitec/Pref. Municipal de Santos, 1995.
} 
Santos - Usoms) que buscaram representar a categoria em suas demandas ao estado e à patronal:

\begin{abstract}
As lideranças não formavam uma casta à parte e os trabalhadores não constituíam uma massa manipulada pelos compromissos políticos de seus dirigentes. Desde o pós-guerra, os êxitos de comunistas e trabalhistas dependiam de seu enraizamento na experiência de classe; sua formação política podia estar tão vinculada à cultura portuária quanto à partidária, e a atuação de muitos militantes intermediários entre bases e cúpulas foi fundamental para dar sustentação ao prestígio desfrutado pelo sindicalismo de inspiração nacionalista. Muitos dirigentes sindicais eram antes de mais nada operários e não foram poucas as vezes que ignoraram ou deram as costas às orientações de cúpulas partidárias para não se verem abandonados pelos trabalhadores, ou porque estavam de fato comprometidos com eles. ${ }^{19}$
\end{abstract}

Assim, em termos gerais, pode-se dizer que essa linhagem analítica da participação dos trabalhadores no processo sócio-político de 1930-1964 colocou em xeque não só a tese de um sindicalismo totalmente cooptado pelo estado, como também questionou (ou pelo menos amainou) as duras críticas direcionadas ao PCB por parte da intelectualidade universitária de esquerda no pós-1964.

Opondo-se, assim, à noção de uma classe trabalhadora "heterônoma" sob a vigência do populismo, essa corrente historiográfica promoveu um resgate das lutas operárias sob o populismo a partir de um registro teórico-interpretativo que as tomou como "lutas por direitos", como lutas dos trabalhadores pela "cidadania".

Pensamos que talvez resida nesse último aspecto uma conexão entre uma revisão historiográfica mais específica, dedicada, como expusemos nas páginas anteriores, ao objeto do "sindicalismo populista", e outra revisão historiográfica de caráter mais geral, voltada para um questionamento do modo como a dominação populista se encontra exposta nos trabalhos de lanni e Weffort. Vejamos isso rapidamente.

Segundo os revisores do populismo em questão, a dominação do estado varguista sobre os setores sociais subalternos teria se dado, entre outros expedientes, por meio da criação e legitimação de uma ampla esfera pública, de natureza eminentemente jurídica e ideológica, que conferiu "cidadania" à classe trabalhadora - o que, aliás, já havia sido destacado pelos próprios Weffort e lanni, como vimos. Entretanto - e aqui se encontra a "inovação" proposta por esta historiografia da Unicamp -, ainda que montada com a finalidade de subordinar os trabalhadores à ordem capitalista brasileira em remodelação, tal esfera acabaria por ter se tornado também um espaço no qual aqueles, portando-se como "cidadãos", lutaram combativamente pelos seus "direitos" por ela estipulados. ${ }^{20}$ Fazendo uso próprio da legislação do Trabalho e dos direitos sociais "concedidos" pela política trabalhista, a classe trabalhadora, por inúmeras vezes, os teria invocado no sentido de exigir, via estado, o cumprimento e aplicação de seus dispositivos legais por parte dos "relapsos"

\footnotetext{
${ }^{19}$ SILVA, Fernando Teixeira da. "Direitos, política...". Op. cit., p. 72. Grifos nossos.

${ }^{20}$ Pode ser interessante assinalarmos aqui, entretanto, que o próprio Octavio lanni já havia dito, que "o populismo da burguesia não é exatamente o populismo das massas assalariadas" (IANNI, Octavio. A formação do Estado populista na América Latina. Op. cit., p. 138.)
} 
industriais, comerciantes e demais segmentos da classe dominante. Nessas inúmeras lutas travadas pelos trabalhadores-cidadãos - enfatizam tais historiadores -, o movimento sindical do período (o "sindicalismo populista" de Weffort) teria desempenhado um papel fundamental, alçando pontes entre as reivindicações operárias, muitas delas pautadas na própria legislação trabalhista vigente, e o poder estatal, responsável por garantir que esta fosse obedecida à risca pelo Capital.

Observando as relações, na década de 1950, entre os portuários santistas, seu sindicato (Sosps), a Companhia Docas de Santos - a concessionária do governo federal para explorar e administrar o Porto da cidade - e o estado populista, Teixeira da Silva exprimiu com clareza a perspectiva acima apresentada:

Com efeito, nos anos 50, a sindicalização atingiu $100 \%$ da categoria e a atuação petebista no Sosp foi fundamental para as primeiras conquistas mais sólidas dos doqueiros, garantidas em convenções coletivas de trabalho que visavam "civilizar a Companhia". ${ }^{21}$ Diversas vezes, entrou em ação contra a empresa a política de relacionamento direto da direção do sindicato com o presidente da República e o Ministério do Trabalho. Na perspectiva de encontrar condições favoráveis à negociação e com o objetivo de criar um contrapeso ao desproporcional peso da Companhia, as relações entre operários e Estado assumem novo significado. A aspiração por direitos, a existência de instituições como a Justiça do Trabalho e a intervenção pessoal de autoridades governamentais, e do próprio presidente da República, tornaram-se instrumentos eficazes para subordinar o poder privado ao "domínio da lei".

Na ótica dos trabalhadores, pelo fato de exercer, em última instância, o controle da indústria portuária, o governo dispunha de mecanismos jurídicos e coercitivos potencialmente capazes de estabelecer a "justiça", obrigando a empresa a cumprir seus deveres, concedendo aos seus empregados o que lhes era "de direito". Essa era a função do "poder central" no que tange às expectativas e exigências de justiça por parte dos operários. O sindicalismo de viés trabalhista foi, sem dúvida, um instrumento eficaz para exprimir e materializar essa representação jurídicopolítica do poder, tornando-se um meio pelo qual dirigentes e comissões de trabalhadores podiam entrar em contato direto com as autoridades. ${ }^{22}$

Em trechos citados anteriormente, pudemos perceber como seus autores procuraram explicitar a existência de um movimento e lideranças sindicais (comunistas e trabalhistas) que, longe de terem sido completamente adormentados pelos instrumentos coercitivos, materiais e ideológicos do estado populista, empreenderam, por diversos meios e táticas (comissões de fábrica, sindicatos paralelos, sindicatos oficias etc.), importantes batalhas contra a dominação exercida por este. Como já apontamos, a ideia de "sindicalismo populista" foi relativizada pelos historiadores campineiros a partir da refutação empírica de muitas das características negativas que a constituíam tal como fora formulada pelos teóricos do populismo. Na lógica expressa no trecho acima, porém, são alguns dos próprios instrumentos da dominação estatal, como o Ministério do Trabalho e a Justiça do Trabalho,

\footnotetext{
${ }^{21}$ Estranhamente, o índice de $100 \%$ de sindicalização é aqui utilizado como uma evidência do êxito do sindicalismo petebista, quando, na verdade, com o chamado closed shopp, praticamente só trabalhava quem era sindicalizado, pouco importando qual era a direção do sindicato ou mesmo seu presidente.

${ }^{22}$ SILVA, Fernando Teixeira da. “Direitos, política...". Op. cit., p. 62. Grifos do autor.
} 
que passam a ter sua natureza política relativizada, a partir da constatação de que, enquanto campos de negociações, conflitos e disputas, teriam sido utilizados pelos trabalhadores em suas lutas cidadãs, nas quais eram ressignificadas noções como "justiça" e "direitos".

Da crítica à forma "reducionista" pela qual a intelectualidade acadêmica marxista dos anos de 1960/70 abordou o sindicalismo brasileiro da etapa populista, nossos historiadores thompsonianos chegaram, portanto, a uma revisão histórica referente às formas pelas quais se operavam as relações de dominação entre estado e trabalhadores no pós-1930. Buscou-se, assim, valorizar um papel ativo dos trabalhadores no âmbito dessas relações, assinalando que muitos deles "extraíram do 'modelo populista' os recursos necessários às suas reivindicações, lutas e ao fortalecimento de suas noções de dignidade e justiça social". ${ }^{23} \mathrm{~A}$ partir de suas próprias "experiências e expectativas", os trabalhadores teriam se apropriado seletivamente de mensagens e discursos oficiais e "operado deslocamentos em seus significados e propósitos originais". ${ }^{24}$ Assim, muitos elementos e práticas da vida sindical "populista" que haviam sido tomadas, pela interpretação sociológica "clássica", como expressões da "cooptação" e "manipulação" dos trabalhadores pelo estado varguista sofreram reinterpretações que, de certo modo, os positivaram. Por conseguinte, uma estirpe de lideranças políticas e sindicais, dantes "cupulista", "colaboracionista" e responsável pelos descaminhos políticos de suas bases operárias, foi reconciliada com estas últimas pelas linhas dos historiadores em questão, livrando-se, assim, de um longo anátema bibliográfico que a acompanhava. Mais uma vez, o trabalho de Fernando Teixeira da Silva sobre os portuários santistas é exemplar dessa matriz interpretativa do populismo:

A experiência cotidianamente vivida nos locais de trabalho era o filtro pelo qual [os trabalhadores portuários] testavam a legitimidade de determinados princípios do ideário trabalhista. Ordenação jurídica da sociedade e legislação do Trabalho não foram meras amarras diluidoras de sua ação, mas um elemento formador de sua cultura e experiências que ameaçavam romper e ultrapassar a lógica de interdependência entre governo e trabalhadores [...]

A explicação do período, baseada na tese do abandono das bases pelas lideranças sindicais, não está convincentemente demonstrada [...]. A crítica ao cupulismo, longe de ter voltado sua atenção para as bases, nas quais depositava suas apostas, lançou suas luzes demasiadamente para o alto. Mas visto num plano mais baixo, onde tudo parecia mera subordinação, existiam experiências democráticas entre trabalhadores e lideranças. Havia também independência em relação ao governo e exercício de uma cidadania que estava longe de ser a simples emanação de um Estado cujo poder se fundamentaria em sua suposta capacidade de cooptar o movimento sindical. Este, por sua vez, não dependia simplesmente de uma bem

\footnotetext{
${ }^{23}$ Idem, p. 80.

${ }^{24}$ Idem. A tese que aponta a utilização particular da legislação trabalhista por parte dos trabalhadores se encontra originalmente, e de modo ainda incipiente, em FRENCH, John D. O ABC dos operários. Conflitos $e$ alianças de classe em São Paulo, 1900-1950. São Paulo: Hucitec/Pref. Mun. de São Caetano do Sul, 1995. Em um trabalho posterior, o historiador brasilianista a desenvolveria, explicitando-a mais e alargando o escopo espacial de sua aplicação: "condenados a atuar no universo fraudulento criado pela CLT - que era manipulada contra os trabalhadores -, os militantes da classe trabalhadora e os sindicalistas, depois de 1943, subverteriam na prática a 'lei' existente por meio de uma luta para fazer da lei (como um ideal imaginário) uma realidade". (__ Afogados em leis. A CLT e a cultura política dos trabalhadores brasileiros. São Paulo: Perseu Abramo, 2001, p.72).
} 
arquitetada manobra no apertado espaço das lutas palacianas, onde pretendiam disputar um lugar ao sol com outras forças políticas. Comunistas e trabalhistas não eram um elemento exterior aos portuários. Eles podiam ser lideranças tanto quanto os trabalhadores o permitissem, traçando os limites de sua atuação. ${ }^{25}$

Expandindo essa nova perspectiva analítica para além do âmbito sindical e militante, alguns desses historiadores tomaram como objeto as relações eleitorais entre determinados contingentes populares e certos políticos populistas. Adriano Duarte e Paulo Fontes, por exemplo, investigando o enorme apoio prestado pelos habitantes dos bairros periféricos paulistanos Mooca e São Miguel Paulista aos políticos Adhemar de Barros e Jânio Quadros, tentaram compreendê-lo por um caminho explicativo alternativo ao da "manipulação" e "cooptação" populistas. Mais uma vez, é a tese da "luta por direitos" que embala tal análise:

\begin{abstract}
As relações entre as classes populares, por meio das organizações de bairro, com os políticos populistas, aqui especificados nas figuras de Jânio e Adhemar, estão muito longe de exprimir alguma ideia de subordinação, inadequação, falsa consciência ou atitudes pré-políticas. Ao contrário, a constante referência, por parte das classes populares, ao poder público como alvo e endereço de suas reivindicações está diretamente ligada à centralidade do seu papel na vida cotidiana do cidadão comum em questões como o saneamento básico, eletrificação, calçamento, transporte e, consequentemente, na definição do que concebiam como direito à qualidade de vida [...].

Os políticos iam ao bairro buscar votos, apoio e reconhecimento; os moradores queriam a ajuda e a intervenção de um político protetor que se colocasse como defensor do bairro e intermediasse junto aos órgãos públicos as suas demandas. E o instrumento dessa barganha foi o voto. Mas essa percepção popular da política era uma via de mão dupla. Ela resultava da percepção que tinham as classes populares de como eram vistos [sic] pelo poder público. ${ }^{26}$
\end{abstract}

Na contramão da interpretação "clássica" quanto à relação líder populista-massas populares, Duarte e Fontes concluem que a maneira destas últimas de se relacionarem com o voto não seria "nem equivocada, nem alienada". Ao contrário, o ato da classe trabalhadora de sufragar nas cédulas eleitorais nomes conservadores como Jânio e Adhemar suporia "uma clara noção de direitos". Por conta disso, seria preciso, segundo nossos historiadores, "relativizar a ideia de que nessa relação de troca não haja implícita uma noção de cidadania e representação". ${ }^{27}$

Sem muito esforço, é possível observar nessa corrente historiográfica uma significativa influência da ideologia da cidadania que, de origem liberal e há muito presente no marxismo de linhagem social-democrata, foi abraçada entusiasticamente por grande parte da intelligentsia petista em meados dos anos 80 e, sobretudo, a partir da década de

\footnotetext{
${ }^{25}$ SILVA, Fernando Teixeira da. "Direitos, política...". Op. cit., p. 81. Grifo nosso.

${ }^{26}$ DUARTE, Adriano; FONTES, Paulo. "O populismo visto da periferia: adhemarismo e janismo nos bairros da Mooca e São Miguel Paulista (1947-1953)”. In: Cadernos AEL: Populismo e trabalhismo (v. 11, n.o 20/21). Campinas: Unicamp/IFCH/AEL, 2004, p. 118-119.

${ }^{27}$ Idem, p. 119.
} 
1990. A adoção de tal ideologia não implicou, entretanto, um abandono da totalidade dos instrumentais marxistas de análise por parte dos historiadores em questão. Assim, ao se deter sobre as atividades sindicais e partidárias dos trabalhadores brasileiros durante o período populista, essa corrente historiográfica ecleticamente amalgamou noções como "luta de classes" e "cidadania", "hegemonia" e "luta por direitos". Provavelmente, esse hibridismo teórico esteja na raiz explicativa do fato de que esses historiadores ao mesmo tempo em que encetaram um indispensável resgate das lutas operárias sob a dominação populista, o fizeram tomando-as, em tom laudatório, como lutas por cidadania.

Rejeitando, ainda que implicitamente, a velha disjuntiva marxista "reforma $x$ revolução", assim como sua correlata leninista "consciência sindicalista $x$ consciência revolucionária", nossos historiadores thompsonianos parecem ter apreendido estas "lutas por direitos" um tanto quanto acriticamente. Embora as tenham enxergado, corretamente, como inegáveis expressões da consciência de classe do proletariado brasileiro da época, nossos historiadores, talvez presos a um certo empirismo, nos dão a impressão de que, para eles, nenhum tipo de qualificação de cunho teórico-político pode ser feita sobre aquela consciência historicamente verificada (como por exemplo, considerá-la como uma subjetividade aquém das possibilidades reais e dos interesses históricos de seus portadores). O fato de que muitas dessas lutas estiveram, segundo os próprios historiadores, calcadas na legislação varguista e imersas no ideário trabalhista, não os leva a, ao menos, excogitar se a consciência alcançada pelos trabalhadores quando destas não estaria ainda cingida ao universo político e ideológico das classes dominantes brasileiras do período - expressando, assim, uma forma de subjetividade heterônoma ("de massa", segundo Weffort e lanni) ou, pelo menos, uma consciência de classe atrasada, rebaixada etc.

Consequentemente, não há espaço na produção dessa corrente para o antigo questionamento, também de procedência marxista, quanto aos limites políticos e históricos das lutas travadas pelos trabalhadores por dentro da ordem social capitalista, assuma essa ordem uma feição política democrático-burguesa, ditatorial, liberal, social-democrata, reformista, populista etc. Por um viés historiográfico social-democrata, as lutas impulsionadas pelos trabalhadores brasileiros por dentro da ordem capitalista de então, a ordem populista, são, por essa corrente, demasiadamente valorizadas, tal como as lideranças sindicais e políticas que estiveram à frente delas, e em nenhum momento têm lugar em seus trabalhos indagações históricas como: por que a classe trabalhadora brasileira não foi capaz de travar um sólido embate contra a dominação populista? Por que sua plataforma política se encontrou em grande parte limitada ao horizonte nacionalreformista? Quais foram os resultados, a médio prazo, do fato de suas lutas terem se referendado nos instrumentos jurídicos e ideológicos trabalhistas (ainda que conferindo a estes um significado próprio)? O que significava, em última análise, o voto operário em nomes como Jânio Quadros e Adhemar de Barros? Quais foram as consequências políticas da eterna "tática", propugnada por muitos dos "comprometidos" dirigentes (pecebistas e petebistas), de colaboração com o estado e os políticos progressistas? Qual a responsabilidade dessas direções pela facilidade com que as classes dominantes saíram 
vitoriosas em 1964? Ou ainda, em nível mais abstrato: o que significa, historicamente, para a classe trabalhadora (seja ela brasileira, haitiana ou francesa), abdicar de uma luta contra a ordem capitalista, qualquer que ela seja?

Por fim, não é escusado explicitarmos aqui que, embora acabe por suavizar alguns dos expedientes da dominação populista sobre os trabalhadores (CLT, estrutura e burocracia sindicais, manipulação e manobra de massas, paternalismo, trabalhismo, assistencialismo social, eleitoralismo, ideologia da "cidadania" e da "colaboração de classes", lideranças operárias colaboracionistas etc.), essa corrente historiográfica não chega a negar a existência desta dominação. Aliás, a importante e eficaz luz lançada por seus membros sobre as várias e diversificadas lutas populares ao longo do populismo já é, por si só, uma evidência de que a dominação de classe se fazia presente tanto no período quanto em suas obras.

Essa perspectiva de interpretação do período 1930-1964, fundamentada em uma leitura de Thompson a partir da valorização da "cidadania", tem como consequência terminológica a recusa à substituição do conceito de populismo pelo de "trabalhismo", tal como propõe o outro campo da revisão historiográfica, o qual discutiremos a seguir. Segundo os historiadores campineiros, nessa troca conceitual se correria o risco de "substituir o estigma pela apologia", ${ }^{28}$ além de que a "ênfase isolada no aspecto trabalhista das relações políticas e sociais" poderia obscurecer "outras dimensões centrais da experiência dos trabalhadores" existentes naquele período, como, por exemplo, a "dimensão urbana". ${ }^{29}$ Para esses historiadores, na medida em que dialoga com um "contínuo fazer-se e refazer-se" das classes populares, o conceito de populismo ainda daria conta de "alguns aspectos da [sua] constituição histórica". ${ }^{30}$ Assim, "ao invés de tomá-lo [o populismo] como um fenômeno imposto de fora para dentro da classe, ou como uma ideologia, que implicaria a manipulação externa", seria adequado "compreendê-lo como um sistema político", isto é, como uma "conjugação complexa e sofisticada de interesses e disputas entre atores desiguais, mas que não prescindia da reciprocidade e da negociação, na qual as classes populares estiveram presentes de forma decisiva". ${ }^{31}$

\section{COMO ERA GOSTOSO O NOSSO POPULISMO: A CORRENTE REVISIONISTA FLUMINENSE}

Embora comungue algumas preferências bibliográficas com a corrente campineira, o outro campo da revisão historiográfica do populismo encerra um conteúdo teórico-político fundamentalmente distinto daquela. Com ampla audiência entre as jovens gerações de pesquisadores alérgicos ao marxismo, e gozando de certo prestígio entre os finórios "comentaristas políticos" dos mass media, o campo aqui alcunhado de revisionista tem

\footnotetext{
${ }^{28}$ FORTES, Alexandre. Nós do Quarto Distrito: a classe trabalhadora porto-alegrense e a era Vargas. Tese (Doutorado em História). Campinas: IFCH, 2001, p. 550.

${ }^{29}$ DUARTE, Adriano; FONTES, Paulo. Op. cit., p. 116

${ }^{30}$ Idem, p. 117.

${ }^{31}$ Idem.
} 
como membros muitos cientistas políticos, sociólogos e historiadores que, não obstante suas diferenças epistemológicas e partidárias, difundem uma visão positivada do varguismo e das instituições políticas da etapa histórica 1930-1964, com ênfase na democracia liberal instituída pela Constituição de 1946.

Fazendo as vezes de "vanguarda acadêmica" desse campo indisfarçavelmente conservador, encontra-se uma corrente composta por conhecidos historiadores da Universidade Federal Fluminense (UFF), a saber, os já referidos Daniel Aarão Reis Filho, Jorge Ferreira e Angela de Castro Gomes. O trabalho mais expressivo das posições historiográficas dessa corrente revisionista fluminense - a qual pode ser considerada como a verdadeira antípoda da teoria do populismo - é a supracitada coletânea $O$ populismo e sua história: debate e crítica, organizada por Ferreira e publicada em 2001. ${ }^{32}$ Trazendo outras contribuições à temática populista escritas por Maria Helena Capelatto, Regina Morel, Elina Pessanha, Lucília Neves Delgado, e mesmo pelos campineiros Hélio da Costa e Fernando Teixeira da Silva (cujos posicionamentos destoam visivelmente dos demais autores), a coletânea reserva um espaço destacado para os artigos dos três maiores expoentes da corrente.

Em trabalhos de cortes espaciais distintos, mas com temporalidades e matriz teórica similares, Angela de Castro Gomes ${ }^{33}$ e Jorge Ferreira ${ }^{34}$ realizaram balanços críticos do conceito de populismo, respectivamente, nas ciências sociais latino-americana e brasileira (em particular). Após mencionarem as primeiras produções bibliográficas sobre o tema, como as provenientes do "Grupo de Itatiaia" de 1952, do Instituto Brasileiro de Economia, Sociologia e Política (IBESP) de 1953, e dos sociólogos argentinos Gino Germani e Torcuato Di Tella, ambos os trabalhos desembocam nos textos de lanni e Weffort, tomados (com razão) como os mais expressivos nos meios acadêmicos nacionais e continentais. Daniel Aarão Reis Filho, em seu artigo O colapso do colapso do populismo ou A propósito de uma herança maldita, ${ }^{35}$ após se deter superficialmente na radicalização política às vésperas da derrubada de Jango, concentrou-se, assim como Ferreira e Gomes, na análise e crítica áspera às concepções de lanni e Weffort.

Detenhamo-nos, muito ligeiramente, sobre algumas das teses revisionistas contidas nesses trabalhos.

Procurando desenvolver as ideias que alinhavara em sua pioneira Invenção do trabalhismo (1988) ${ }^{36}$, Angela de Castro Gomes, no artigo da coletânea em questão, argumentou que a noção de "manipulação de massas" utilizada por Weffort, embora fosse dotada de uma "intrínseca ambiguidade" (por expressar "tanto uma forma de controle do

\footnotetext{
${ }^{32}$ FERREIRA, Jorge (org.). O populismo e sua história. Debate e crítica. Op. cit.

${ }^{33}$ GOMES, Angela de Castro. "O populismo e as ciências sociais...". Op. cit. Este artigo, publicado anteriormente em 1996 (Tempo. Revista do Departamento de História da Universidade Federal Fluminense, vol. I, n.o 2. Rio de Janeiro: Relume-Dumará, 1996), recebeu a adição de um "pós-escrito" em sua versão contida na coletânea de 2001.

${ }^{34}$ FERREIRA, Jorge. "O nome e a coisa...". Op. cit.

${ }^{35}$ REIS FILHO, Daniel Aarão. "O colapso do colapso do populismo ou a propósito de uma herança maldita". Op. cit.

${ }^{36}$ GOMES, Angela de Castro. A invenção do trabalhismo. Op. cit.
} 
estado sobre as massas quanto uma forma de atendimento de suas reais demandas"), ${ }^{37}$ teria (equivocadamente) apresentado

\begin{abstract}
uma relação em que um dos termos é concebido como forte e ativo, enquanto o outro é fraco e passivo, não possuindo capacidade de impulsão própria por não estar organizado como classe. As massas ou os setores populares, não sendo concebidos como atores/sujeitos nesta relação política, mas sim como destinatários/objetos a que se remetem as formulações e políticas populistas, só poderiam mesmo ser manipulados ou cooptados (caso das lideranças), o que significa precipuamente, senão literalmente, enganados ou ao menos desviados de uma opção consciente. ${ }^{38}$
\end{abstract}

Consequentemente, para o trato historiográfico das relações entre estado e trabalhadores no pós-1930, Angela Gomes propôs, desta vez explicitamente, a categoria de "trabalhismo" como substitutiva da de populismo. Na ótica da historiadora, enquanto a ideia de populismo traria a errônea compreensão de que os trabalhadores teriam sido "manipulados" e "manobrados" pelo estado, o conceito de "trabalhismo" atribuiria aos primeiros "um papel ativo, vale dizer, uma presença constante na interlocução com o Estado", reconhecendo "um diálogo entre atores com recursos de poder diferenciados, mas igualmente capazes não só de se apropriar das propostas político-ideológicas um do outro, como de relê-las". ${ }^{39}$

Seguindo o caminho interpretativo proposto por Gomes, o revisionista Jorge Ferreira elevou o volume da crítica aos teóricos do populismo. Dispensando os cuidados e ressalvas da refinada historiadora - que, como vimos, reconheceu, por exemplo, que noção weffortiana de "manipulação de massas" continha uma "intrínseca ambiguidade" -, Ferreira procurou negar por completo a teoria "populista". Em "O nome e a coisa: o populismo na política brasileira" 40, o historiador a acusou de retratar de forma "maniqueísta" ${ }^{41}$ o relacionamento entre a máquina estatal getulista e a classe trabalhadora que adentrava o cenário político-institucional no pós-1930; para Ferreira, por terem se inspirado no conceito gramsciano de "hegemonia" ${ }^{42}$, os estudos calcados na ideia de populismo acabaram por tomar o estado como uma entidade todo-poderosa, ao passo que os trabalhadores (ou, simplesmente, a "sociedade", como por vezes escreve o historiador) teriam sido neles retratados apenas como pobres vítimas inermes:

Culpabilizar o Estado e vitimizar a sociedade, eis alguns dos fundamentos da noção de populismo [...].

Como uma via de mão única, de cima para baixo, à luz do enfoque opressor e oprimido, o Estado, todo-poderoso, pela violência física e ideológica, domina e subjuga a sociedade, os trabalhadores em particular, surgindo, desse modo, uma

\footnotetext{
${ }^{37}$ GOMES, Angela de Castro. "O populismo e as ciências sociais...". Op. cit., p. 34.

${ }^{38}$ Idem, p.34-35.

${ }^{39}$ Idem, p. 46.

${ }^{40}$ FERREIRA, Jorge. “O nome e a coisa...”. Op. cit.

${ }^{41}$ Idem, p. 95.

${ }^{42}$ Idem, p. 85.
} 
relação destituída de interação e interlocução entre as partes. O Estado, com um poder desmedido, "total" em algumas versões, transforma a sociedade em elemento passivo, inerte e vitimizado. Assim, no Brasil, em 1930, 1935 ou certamente 1937, os governantes, armados com variados dispositivos "simbólicos" de dominação ideológica, em alguns casos psicológica, teriam tido a capacidade de manipular, por meio de imagens e representações, as emoções e a sensibilidade das pessoas, dominando, inclusive, as suas mentes. ${ }^{43}$

A débil colocação de Ferreira nos impele a alguns breves comentários críticos. Primeiramente, por um simples critério de honestidade intelectual, devemos sublinhar que, conforme já expusemos neste artigo, tanto Weffort como lanni não fizeram uso da noção de "manipulação de massas" do modo como Ihes seria depois atribuído por Ferreira. Ambos deixaram claro, em várias passagens de seus trabalhos - e Angela Gomes bem o percebeu -, que a "manipulação" do estado sobre os setores subalternos assentava-se, essencialmente, no atendimento por parte do primeiro a determinadas demandas sociais dos últimos. De modo algum, tal "manipulação" foi por eles interpretada como um fenômeno de ordem meramente ideológica, calcado simplesmente na eficácia demagógica das lideranças populistas. Em seu mais conhecido texto, Weffort foi explícito ao dizer que

a noção de manipulação, tanto quanto a de passividade popular, precisa ser relativizada, concretizada historicamente, para que possamos entender a significação real do populismo. A imagem, se não o conceito, mais adequada para entendermos as relações entre massas urbanas e alguns grupos representados no Estado é a de uma aliança (tática) entre setores de diferentes classes sociais na qual evidentemente a hegemonia encontra-se sempre ao lado dos interesses vinculados às classes dominantes, mas torna-se impossível de realizar-se sem o atendimento de algumas aspirações básicas das classes populares, entre as quais a reivindicação do emprego, de maiores possibilidades de consumo e de direito de participação nos assuntos do Estado. Aspirações mínimas, por certo, mas decisivas na política de massas num país como o Brasil. ${ }^{44}$

Em A formação do Estado populista na América Latina, de 1975, lanni também demonstrou nutrir a mesma preocupação de Weffort a respeito de possíveis depreensões simplistas da noção de "manipulação de massas". Dialogando com a incipiente bibliografia até então existente sobre a temática populista, o sociólogo criticou justamente certas análises que apresentavam as massas urbanas como um "elemento passivo, manipulado de cima"; para lanni, tal entendimento expressaria uma "contradição em termos", já que, "na medida [em] que o populismo se funda na aliança de classes - e este é um conteúdo essencial do seu policlassismo - deve haver algum tipo de barganha entre as classes da coalizão" ${ }^{45}$

Em segundo lugar, convém colocar que, ainda que tenha sido objeto de distintas apreensões, o conceito gramsciano de "hegemonia" - cuja utilização, segundo Ferreira,

\footnotetext{
${ }^{43}$ Idem, p. 63-94

${ }^{44}$ WEFFORT, F. "O populismo na política brasileira". In: 75-76. Grifos nossos.

${ }^{45}$ IANNI, Octavio. A formação do Estado populista na América Latina. Op. cit., p. 42-43.
} 
estaria na base de uma visão "maquiavélica" de lanni e Weffort sobre as relações entre "Estado e sociedade" no 1930-1964 - diz respeito, segundo quase todos os intérpretes do marxista sardo, a uma forma particular de dominação político-social, na qual a classe ou fração de classe dirigente combinaria elementos de consenso e de coerção no seu exercício de direção da Nação. ${ }^{46}$ Desse modo, não é necessário envidar muitos esforços para se perceber que a noção de "hegemonia", ao menos no seu sentido gramsciano, nada tem a ver com a dicotomia estado forte ("culpado") x sociedade fraca ("vítima"), falsamente atribuída aos teóricos do populismo. Ademais, nas elaborações destes últimos, em especial nas de Weffort e lanni, a emergência do populismo derivaria justamente de uma ausência de hegemonia ("crise de hegemonia"), de sorte que o "Estado de compromisso", forjado com a "Revolução de 1930", seria justamente uma solução encontrada para a inexistência de um grupo social hegemônico face à débâcle da antiga hegemonia da oligarquia cafeicultora. Por conseguinte, a proposta interpretativa do estado populista como um "estado de compromisso" aproxima-se, a nosso juízo, muito mais da ideia marxista de regime bonapartista do que de um raciocínio de tipo weberiano que vislumbra uma submissão da "sociedade" a um estado de natureza "patrimonialista". ${ }^{47}$

Porém, o mais curioso (e um tanto quanto estapafúrdio) da crítica de Ferreira é que, após adjudicar erroneamente à teoria do populismo uma concepção "maniqueísta" e antitética da relação entre "estado" e "sociedade", foi o próprio historiador quem, guiado, ele sim, pela lógica formal, acabou por adotar uma visão pueril sobre tal relação, conferindoIhe, ao final, um sentido positivo. Tomando abstratamente conceitos como "estado" e "sociedade" - ignorando, assim, o caráter de classe do primeiro e o antagonismo estruturante da segunda - Ferreira propôs uma interpretação histórica do Brasil pós-1930, na qual a relação entre ambos se encontraria equalizada, tendendo a uma harmonização, e não mais à oposição. À maneira idealista, Ferreira procurou, desse modo, conciliar aquilo que a teoria do populismo teria, supostamente, separado. Na verdade, o historiador revisionista não faz mais do que, por intermédio de um balanceamento dos termos da relação ("estado - sociedade"), reafirmar a mesma matriz teórica liberal que informa a tese de um "estado" que subjuga a "sociedade"; a diferença é que, no texto de Ferreira, a

\footnotetext{
${ }^{46}$ Convém apontar que, entretanto, a dosagem desses componentes na fórmula hegemônica também é objeto de polêmica entre os estudiosos do marxista sardo. A ideia de que, para Gramsci, a "hegemonia" se constituiria em uma relação equilibrada entre coerção e "consenso", na qual a significativa presença do segundo não retiraria o caráter fundamental da primeira - pode ser encontrada, por exemplo, em BIANCHI, Alvaro. $O$ laboratório de Gramsci. Filosofia, história e política. São Paulo: Alameda, 2008. Todavia, outros renomados especialistas em Gramsci, de linhagem eurocomunista, trabalham com a perspectiva de que uma dominação hegemônica estaria baseada fundamentalmente nos aspectos de ordem consensual. Ver, entre outros trabalhos, COUTINHO, C. N. Gramsci: um estudo sobre seu pensamento político. Rio de Janeiro: Civilização Brasileira, 1999 e . Intervenções: o marxismo na batalha de ideias. São Paulo: Cortez, 2006.

${ }^{47}$ Uma exposição desta nossa tese (que afirma ser a teoria do "populismo" de Weffort e lanni embasada, em grande parte, na noção marxista de bonapartismo) pode ser encontrada em DEMIER, Felipe. O longo bonapartismo brasileiro (1930-1964): "autonomização relativa do Estado", populismo, historiografia e movimento operário. Tese (Doutorado em História). Niterói: PPGH, 2012. Uma visão mais resumida pode ser vista em "Bonapartismo e cesarismo nos estudos sobre o populismo brasileiro". In: Outubro. n.o 19, 2011, p. $\overline{105-154 .}$
} 
suposta subjugação deu lugar a uma espécie de cumplicidade harmônica. De uma forma ou de outra, opostos ou não, aliados ou adversários, "estado" e "sociedade" não parecem estar, na análise do autor, atravessados pela luta de classes:

\begin{abstract}
Na época do "primeiro governo" Vargas, muitas foram as denúncias deste tipo ["muitos teriam escrito cartas a Vargas, ao Dops ou à polícia denunciando os opositores do regime porque se encontravam atemorizados, ou aterrorizados, com as supostas ameaças dos inimigos, reais ou fictícios, ao governo e, portanto, à ordem social"], e, hoje, facilmente as encontramos no Arquivo Nacional ou nos arquivos do Dops. São delações de que o vizinho era integralista ou comunista; as famílias alemãs não falavam português; o comerciante da esquina estocava alimentos; o fulano era um conhecido agiota. Todas as denúncias eram seguidas de nomes e endereços. Supor que as pessoas delatavam as outras por pressões "simbólicas" do Estado é ter como premissa que a sociedade, em seu estado "normal", seria "boa", mas, ao ser corrompida moralmente pelos governantes do Estado Novo, ter-se-ia transformado em um bando de delatores. Mais difícil, repito, é compreender que a sociedade, em si mesma, não era tão "boa" e isenta de culpas, e que nela circulavam preconceitos contra judeus; manifestavam-se rancores contra alemães e japoneses, sobretudo durante a Segunda Guerra Mundial; existiam pessoas com horror dos comunistas ou dos integralistas; encontravam-se alguns que queriam punir o comerciante da esquina desmedido em seus lucros; havia outras que desejavam livrar-se das dívidas com o agiota - e, em alguns casos, do próprio marido. Se havia uma ditadura que se mostrava disposta a ajudá-las, o caminho ficava mais fácil. Em outras palavras, as relações entre Estado e sociedade não eram de mão única, de cima pra baixo, mas, sim, de interlocução, de cumplicidade. ${ }^{48}$
\end{abstract}

Assim, tratados pelo historiador como categorias estanques, "estado" e "sociedade" teriam, sob a ditadura estadonovista, compartilhado a "maldade" humana, antes supostamente vista como um apanágio exclusivo do estado. Com efeito, distante das linhas de Ferreira está a ideia de que o estado, grosso modo, posta-se como o representante de uma ou mais partes da sociedade contra outras partes dessa mesma sociedade e que, portanto, não há, senão para a velha filosofia idealista burguesa, uma relação entre a "sociedade" in totum e o "estado". O mesmo tipo de raciocínio liberal pode ser encontrado nas análises de Daniel Aarão Reis Filho sobre os buliçosos momentos finais do governo Goulart, quando "a sociedade", segundo o historiador, foi "chamada a decidir se queria, ou não, e de que forma, as tão propaladas reformas [de base]". ${ }^{49}$

Deixando transparecer suas preferências políticas no tempo passado (e talvez também no tempo presente), os historiadores revisionistas finalmente apontaram aquele que teria sido o elemento mediador/conciliador entre "estado" e "sociedade": a tradição trabalhista.

Talvez seja o caso de falar um pouco desta tradição, uma vez que impregna, embora largamente rejeitada, a história do país a partir dos anos 40 . Constituiu-se no quadro do processo de urbanização e de industrialização, e se caracterizava por

\footnotetext{
${ }^{48}$ FERREIRA, Jorge. "O nome e a coisa...". Op. cit., p. 94-95.

${ }^{49}$ REIS FILHO, Daniel Aarão. "O colapso do colapso do populismo ou a propósito de uma herança maldita". Op. cit., p. 340.
} 
um programa nacionalista, estatista e popular. Autonomia no quadro das relações internacionais, com a definição do que então se chamava uma política externa independente. Estado intervencionista no campo econômico, regulador, desenvolvimentista. Redes de proteção para os trabalhadores: institutos de aposentadorias e pensões, sindicatos assistencialistas, justiça do trabalho, em cuja administração as lideranças sindicais participavam ativamente: uma cornucópia. Sem contar as empresas diretamente controladas pelo Estado, as estatais, com seus generosos planos de carreira, financiamentos específicos e proteção contra o desemprego [...].

Às vésperas da instauração da ditadura, em março de 1964, [a "tradição trabalhista"] adquirira já uma identidade relativamente consolidada, carregando, nos centros urbanos, boa parte dos votos dos trabalhadores assalariados. $\mathrm{E}$ aparecia na liderança das lutas nacionalistas (contra o capital estrangeiro, por uma lei rigorosa sobre remessa de lucros para o exterior, pela afirmação do poder e da cultura nacionais), pela distribuição de renda (aumentos salariais, reforma tributária) e de poder (voto para os analfabetos e para os graduados das forças armadas, controle sobre o poder econômico nas eleições etc. $)^{50}$

Se, para Daniel Aarão Reis Filho, o "trabalhismo" foi visto como esse cabedal de direitos dos assalariados, como essa fonte abundante de benefícios sociais ("uma cornucópia"!!!) que - tal como a burocracia prussiana para o velho Hegel - teria permitido uma harmonização entre "estado" e "sociedade", Jorge Ferreira, por sua vez, não ficou atrás em sua nostalgia do varguismo, ao considerar que

embora diversificado e apropriado por organizações da sociedade civil, o trabalhismo orientou-se por um eixo, por uma estrutura dorsal nacionalista, distributivista e desenvolvimentista, permitindo a construção de um projeto para o país, marcado por forte solidariedade. ${ }^{51}$

Afastando-se de qualquer tradição teórica embasada na crítica social, e obliterando a dimensão do conflito de classes na arena histórica, Ferreira chegou a promover, via "trabalhismo", uma identificação quase completa entre "estado" e "trabalhadores" (os quais, por vezes - repetimos -, aparecem como sinônimo de "sociedade" e vice-versa):

Houve, decerto, a intervenção estatal, insisto. Sobretudo a partir de 1942, a formulação do projeto trabalhista pelo Estado contribuiu, de maneira decisiva, para configurar uma identidade coletiva da classe trabalhadora. Mas, em qualquer experiência histórica, os assalariados sofrem influências dos contextos sociais, políticos e ideológicos em que vivem. No caso brasileiro, como em outros, tratou-se de uma relação, em que as partes, Estado e classe trabalhadora, identificaram interesses em comum. No trabalhismo, estavam presentes ideias, crenças, valores e códigos comportamentais que circulavam entre os próprios trabalhadores muito antes de 1930. Compreendido como um conjunto de experiências políticas, econômicas e sociais, ideológicas e culturais, o trabalhismo expressou uma consciência de classe, legítima porque histórica. ${ }^{52}$

\footnotetext{
50 Idem, p. 345-346.

${ }^{51}$ FERREIRA, Jorge. "Introdução". In:_____ (org.). O populismo e sua história. Debate e crítica. Op. cit., p. 1415.

${ }^{52}$ FERREIRA, Jorge. "O nome e a coisa". Op. cit., p. 103. Grifo do autor.
} 
O trecho acima talvez possa ser considerado a fina flor do pensamento revisionista, uma espécie de síntese dessa indisfarçada apologia da Era Vargas.

Em um verdadeiro devaneio keynesiano, é proposta a ideia de que, sob o "trabalhismo", estado e trabalhadores "identificaram interesses em comum". A nosso ver, a asserção de que, em um significativo espaço de tempo como o período populista (1930-1964) - e não em um ou outro momento episódico, como uma guerra, uma catástrofe natural etc. - pode ter havido uma comunhão de interesses entre o proletariado e a máquina estatal capitalista é um tanto quanto absurda, não requerendo sequer uma crítica mais elaborada aqui.

Igualmente inconsistente teórica e historicamente, a ousada interpretação do trabalhismo como uma "legítima" expressão da "consciência de classe" dos trabalhadores brasileiros expõe um distanciamento/oposição do autor em relação a toda uma tradição marxista dedicada à temática da subjetividade política dos estratos subalternos. Reparemos que já não se trata, como no caso dos historiadores campineiros, de uma valorização acrítica das formas rebaixadas de subjetividade dos trabalhadores (consciência sindicalista, reformista etc.) verificadas no período populista: agora, é o trabalhismo getulista, uma ideologia político-social gestada pela cúpula dirigente do estado brasileiro - e isso os próprios revisionistas reconhecem - que é apontada como uma verdadeira, legítima e inquestionável consciência de classe do proletariado nacional (!!!)

O que se encontra subjacente nessa identificação entre "trabalhismo" e "consciência de classe" proposta por Jorge Ferreira (e, mais discretamente, pelos demais revisionistas) é uma perspectiva teórica conhecida como marxismo analítico (também chamada de marxismo da escolha racional), desenvolvida por autores como Adam Przeworski e Jon Elster. Ecleticamente fundindo uma sociologia marxista das "classes sociais" com a categoria weberiana de "ação racional", esse amálgama teórico contém ainda, sub-repticiamente, alguns preceitos vulgares da economia política neoclássica utilitarista (como o do homo economicus - que já se fazia presente, aliás, na economia burguesa clássica -, cujas ações buscariam maximizar lucros e minimizar prejuízos); dessa forma, o marxismo analítico simplesmente descarta a noção marxiana de "ideologia", a nosso ver, indispensável para o entendimento das relações entre as classes dominantes e dominadas, particularmente no que diz respeito à sustentação social que as últimas (salvo nas situações excepcionais, revolucionárias) oferecem aos regimes políticos das primeiras. ${ }^{53}$

\footnotetext{
${ }^{53}$ Uma crítica ao marxismo analítico pode ser encontrada em BENSAID, Daniel. Marx, o intempestivo. Rio de Janeiro: Civilização Brasileira, 1999, p. 62-103. Quanto à sua adoção por parte dos autores revisionistas, vale mencionar a influência recebida da obra de Argelina Figueiredo, Democracia ou reformas? Alternativas democráticas à crise política: 1961-1964 (São Paulo: Paz e Terra, 1993), que introduziu no Brasil a vertente teórica em questão. Assim como nos trabalhos dos revisionistas do populismo, há na obra de Argelina Figueiredo um forte teor antimarxista, que a leva a responsabilizar a esquerda brasileira pelo fim do regime "democrático" (1945-1964). Uma interessante crítica à perspectiva interpretativa de Figueredo acerca do Golpe de 1964 (assim como a outros autores que a seguiram, como os próprios Daniel Aarão Reis Filho e Jorge Ferreira) pode ser encontrada em MELO, Demian. "A miséria da historiografia". In: Outubro, n.o 14. São Paulo: Alameda, 2006, p. 111-130, além do texto desse mesmo autor que compõe a presente obra (ver também TOLEDO. Caio Navarro de. “As falácias do revisionismo". In: Crítica Marxista, n.o 19. Campinas: 2004, p. 27-48).
} 
Com o fito de combater a ideia da "manipulação das massas" propugnada por Weffort e lanni, os revisionistas esgrimiram, assim, o argumento de que se as massas populares apoiaram, por várias vezes, as lideranças políticas do regime varguista, foi única e exclusivamente porque elas assim o quiseram ou, continuando o silogismo antidialético, foi porque os chefes trabalhistas e afins eram, de fato, representantes das vontades populares mais intensamente sentidas. Apresentado como uma simples opção racional dos trabalhadores brasileiros, o engenhoso trabalhismo construído por Vargas, Marcondes Filho e cia., fundamental na estrutura populista de dominação política sobre os trabalhadores, foi simplesmente positivado pela historiografia revisionista. Como bem afirmou Marcelo Badaró Mattos, a crítica ao conceito de populismo proposta por essa historiografia acabou por

enredar-se na mesma polarização política da época, embora no polo oposto, ao defender abertamente os argumentos usados pelos "acusados" de populistas, ou seja, de que na verdade eram legítimas lideranças populares e progressistas, acusados por uma elite conservadora que não se conformava com a entrada na cena política dos trabalhadores. ${ }^{54}$

Sob um registro teórico que diz conceber os trabalhadores brasileiros como sujeitos de sua própria história, escamoteia-se nesses trabalhos revisionistas uma perspectiva analítica profundamente conservadora, a qual tem como precípuo objetivo historiográficopolítico (ou talvez político-historiográfico) promover uma positivação das formas populistas de dominação de classe. Trata-se, na verdade, de uma defesa populista do populismo. Ou ainda, jogando com as palavras do próprio Ferreira, poderíamos dizer que os revisionistas reivindicam a "coisa" (populismo), embora rejeitem seu "nome" (populismo).

HISTORIADORES, POLÍTICA, PASSADO E PRESENTE: UMA INDAGAÇÃO À GUISA DE CONCLUSÃO

Tem sido muito comum entre os membros e adeptos desta última corrente analisada, a revisionista, relacionar a concepção clássica (marxista) do conceito de populismo às trajetórias políticas de seus principais formuladores. Segundo essa proposta associativa entre política e teoria, intelectuais como lanni e Weffort, por terem se situado em um plano teórico-político à esquerda do PCB nos anos de 1960 e 70, teriam atribuído ao partido uma exagerada responsabilidade pelo desfecho trágico de 1964, ao mesmo tempo em que acabaram por estigmatizar a forma como a classe trabalhadora portou-se face ao estado e às classes dominantes no período 1930-1964.

Assim, o próprio conceito de populismo, segundo os revisionistas, não passaria, como já dissemos, de uma invenção de cunho pejorativo, fruto de uma ampla aliança ideológica contra o "trabalhismo", a qual incluiria desde os teóricos do populismo, que denunciavam a "manipulação" dos trabalhadores pelo varguismo e seus colaboradores (com

\footnotetext{
${ }^{54}$ MATTOS, Marcelo Badaró (coord.), et. al. Greves e repressão policial ao sindicalismo carioca (1945-1964). Rio de Janeiro: APERJ/FAPERJ, 2003, p. 28-29.
} 
ênfase no PCB), até a direita tradicional brasileira e seus ideólogos, sempre hostis à participação dos setores populares na cena política nacional. Para os revisionistas, esboçada nas décadas de 1940 e 1950 (a partir da junção de jornalistas liberais, adversários da política social varguista e até mesmo de intelectuais isebianos, responsáveis pelas primeiras elaborações sobre o populismo),

foi nos anos 60, sobretudo a partir de 1963, que a aliança se ampliou enormemente. Além da imprensa e de novos sociólogos, agora nas universidades, agregaram-se os militares golpistas, a direita civil, a Igreja, os capitalistas, as classes médias conservadoras e os crentes da ortodoxia marxista-leninista. Todos, no dizer de Daniel Aarão Reis Filho, tinham as contas a ajustar com o grande inimigo: o trabalhismo. E tão liquidado o queriam, que o defunto sequer teve o direito de levar seu próprio nome ao túmulo: "batizado pela sociologia paulista, foi como populismo que desceu aos sete palmos da terra. $E$, assim, seria ensinado às novas gerações, nas escolas, nos quartéis e nas organizações políticas". E, como diz o autor, "temos as contas acertadas". ${ }^{5}$

Também segundo esse raciocínio, em fins dos anos de 1970, a adesão "ideológica" dos principais teóricos do populismo ao "novo sindicalismo" e ao (ainda em construção) Partido dos Trabalhadores (PT), então adversários do PCB no interior do processo de reorganização da esquerda brasileira, os teria levado a intensificar suas críticas à atuação dos comunistas no pré-1964. Assim, os balanços negativos feitos por lanni e (principalmente) Weffort sobre o "velho sindicalismo" ("sindicalismo populista") e o papel nele desempenhado pelo PCB não passariam, segundo a lógica revisionista, de visões e discursos sobre o passado motivados pelas opções político-ideológicas de seus autores no tempo presente:

\begin{abstract}
Não estudar os fundamentos históricos e sociais deste processo [1945-64], e a pretexto de que sofreu uma derrota política tentar definir e demonizar bodes expiatórios, distorcer referências, invertendo sinais e mudando nomes, é pavimentar o caminho para novas - e graves - derrotas.

As esquerdas autodenominadas revolucionárias, nos anos 60 , enveredaram por este caminho. Olhando para o futuro, eliminaram o passado. Figurando-se como marco zero, desprezaram experiências e tradições e deram um salto - uma fuga para frente. Também por este motivo foram destruídas.

O Partido dos Trabalhadores, o PT, e muitos de seus intelectuais - entre os quais figurou, em certo momento, F. Weffort, e entre os quais está ainda a maioria dos autores que trabalham com a teoria populista - fizeram opção semelhante. Antes, pela revolução. Agora, pela democracia. Sempre, um novo marco zero. ${ }^{56}$
\end{abstract}

Com efeito, conforme nós mesmos afirmamos logo nos primeiros parágrafos sobre a teoria do populismo, existiu uma relação entre seu surgimento/desenvolvimento e os contextos históricos nos quais seus elaboradores estiveram envolvidos. Portanto, em nosso entendimento, as opções políticas de intelectuais como lanni e Weffort nos anos de 1960 e 70 certamente guardam uma relação com seus escritos sobre a história do movimento

\footnotetext{
${ }^{55}$ FERREIRA, Jorge. "O nome e a coisa”. Op. cit., p. 121. Grifo do autor.

${ }^{56}$ REIS FILHO, Daniel Aarão. Op. cit., p. 374-375. Grifo do autor.
} 
operário e sindical brasileiro do pós-1930. Não há "neutralidade científica". Não somos positivistas.

Porém, consideramos profundamente equivocado reduzir as profícuas análises desses cientistas sociais sobre o complexo populismo brasileiro a uma espécie de "construção ideológica" determinada - ou, como querem os revisionistas, "comprometida" única e exclusivamente por suas preferências programáticas no então tempo presente. Para além de seus alinhamentos político-partidários antes e depois do Golpe de 1964 (e, em particular, durante os anos da transição da Ditadura ao regime democrático-liberal), e a despeito de seus ulteriores (e opostos) posicionamentos políticos, ${ }^{57}$ os teóricos marxistas do populismo trouxeram à tona em seus trabalhos, como pudemos ver, aspectos fundamentais para a compreensão do processo sócio-político brasileiro ocorrido entre 1930-1964. Dialogando com as linhas interpretativas então em voga, articulando distintas temporalidades ("durações"), diferentes níveis de análise, e coadunando elementos estruturais e conjunturais (assim como internacionais e nacionais), lanni e Weffort propuseram interpretações que, a nosso ver, mostraram-se exitosas em captar os principais eixos daquele movimento histórico pelo qual o Brasil se tornou uma sociedade urbanoindustrial e politicamente de massas. Indubitavelmente, essas interpretações - até mesmo pelo seu escopo e porte - continham falhas e lacunas: enquanto alguns historiadores tentaram (tentam) corrigi-las e supri-las (respectivamente), outros, sectariamente, optaram (optam) por simplesmente rejeitar todo o conjunto da obra, lançando-lhe a pecha de "ideológica".

Entretanto, se esse último procedimento, como dissemos, se mostra equivocado e reducionista, o exercício de buscar, no presente, as raízes sociais para as elaborações científicas sobre o passado nos parece, em si, bastante sugestivo. Assim, poderíamos, por exemplo, sugerir um vínculo entre a reabilitação historiográfica das práticas sindicais comunistas sob o populismo, promovida pelos historiadores campineiros, e a orgânica participação de alguns deles nas fileiras do PT ao longo das décadas de 1990 e 2000 (quando justamente a "colaboração de classes" e a "concertação social" afirmavam-se como linhasmestras do sindicalismo petista). Tal sugestão - frisamos - não poderia, entretanto, reduzir as competentes pesquisas históricas campineiras às opções políticas de seus autores.

Desse modo, talvez valha a pena, então, aplicar esse mesmo exercício também àqueles que propuseram o enterro, sem exéquias, da teoria do populismo. Chegamos, assim, a uma indagação que finaliza este artigo: haveria alguma relação entre a defesa do "trabalhismo" e de seus chefes, efetuada pelo movimento historiográfico revisionista, e os

\footnotetext{
${ }^{57}$ Enquanto Octavio lanni manteve-se numa postura crítica ao capitalismo até o final de sua vida (2004), Francisco Weffort promoveu uma brusca inflexão em sua trajetória política. Ainda que cada vez mais moderado, o cientista político manteve-se, até a metade da década de 1990, ligado à esquerda, ocupando uma posição de destaque no interior do PT. Entretanto, quando da vitória eleitoral de Fernando Henrique Cardoso sobre Luís Inácio Lula da Silva no pleito presidencial de 1994, Weffort, que havia sido um dos organizadores da campanha do candidato petista, aceitou, surpreendentemente, o convite do vitorioso para estar à frente do Ministério da Cultura, ocupando assim o cargo de ministro durante todos os dois mandatos de FHC (1995-2002).
} 
atuais posicionamentos públicos de alguns dos seus principais expoentes diante de questões da vida política, sindical e universitária brasileira? 